\title{
INHIBITION OF STREPTOLYSIN S BY THE SERUM OF PA- TIENTS WITH RHEUMATIC FEVER AND ACUTE STREPTOCOCCAL PHARYNGITIS ${ }^{1}$
}

\author{
By GENE H. STOLLERMAN 2 AND ALAN W. BERNHEIMER \\ (From the Department of Microbiology, New York University College of Medicine and \\ College of Dentistry, and the Streptococcal Disease Laboratory, Fort Francis E. \\ Warren Air Base, Wyoming)
}

(Submitted for publication May 4, 1950; accepted, May 29, 1950)

The "antistreptolysin S" titers of the sera of patients with rheumatic fever were first studied by Todd, Coburn and Hill (1). These authors demonstrated that during the course of this disease there was a tendency for the antistreptolysin $S$ titer to fall and to be lowest when clinical symptoms were most severe. This observation is in striking contrast to the immune response of patients with rheumatic fever to a number of other biologically active substances produced by Group A streptococci (Streptococcus pyogenes). Thus, increases in antibodies to streptolysin $\mathrm{O}$, streptokinase, hyaluronidase and desoxyribonuclease appear frequently during rheumatic fever and following streptococcal infections (2-5). The immune response of these patients to streptolysin $\mathrm{S}$ has been less clearly understood. Despite the fact that streptolysin $\mathrm{S}$ is produced by almost all strains of Streptococcus pyogenes, and has been shown to be responsible for the familiar phenomenon of beta hemolysis on the surface of blood agar plates (6), there have been relatively few studies of its biological activity, and its antigenic properties have not been clarified.

Streptolysin S was first clearly differentiated from the better known streptolysin $O$ by the studies of Todd (7). It had originally been demonstrated by Weld (8) that streptococci produce a powerful hemolysin upon shaking the cells of young cultures in the presence of horse serum. This hemolytic toxin, produced in the presence of

1 The studies at New York University were supported in part by grants from the Life Insurance Medical Research Fund and the Masonic Foundation for Medical Research and Human Welfare. Studies at Fort Francis E. Warren Air Base were supported through the Commission on Acute Respiratory Diseases, Armed Forces Epidemiological Board, through funds made available by the Army Medical Research and Development Board.

2 Fellow of the Dazian Foundation for Medical Research. serum, was named streptolysin $\mathrm{S}$ by Todd to distinguish it from the oxygen-labile hemolysin, streptolysin $\mathrm{O}$, which is formed in broth cultures in the absence of serum.

The two streptococcal hemolysins could be further differentiated on immunological grounds: Streptolysin $O$ proved to be an excellent antigen but streptolysin S did not appear to be antigenic when separated from the organisms. Todd found, however, that elevated antistreptolysin S titers occurred in a small percentage of rabbits intensively immunized with living cultures of hemolytic streptococci. Moreover, Todd, Coburn and Hill (1) appeared to regard the antistreptolysin S titer of human sera as due to a specific antibody, and the fall in titer occurring during rheumatic activity presumably as evidence of an abnormal antibody response.

The present study confirms the phenomenon of decreased antistreptolysin $\mathrm{S}$ titers in the sera of patients with clinically active, acute rheumatic fever. It also demonstrates the failure of patients with streptococcal pharyngitis to show a rise in serum titer against streptolysin $S$. These facts, considered in conjunction with the constancy and narrow range of antistreptolysin $\mathrm{S}$ titer in normal human sera, suggest that the inhibition of this streptococcal hemolysin is due to a normal serum inhibitor distinct from specific antibody. Further evidence for this view has been provided by the demonstration that a wide variety of normal animal sera also inhibit the toxin within a narrow range of relatively low dilutions and that the serum inhibitor can be separated from antibodies by fractionation with ammonium sulfate and with alcohol at low temperatures (9-11). It seems wise, therefore, to abandon the use of the term "antistreptolysin S," since this denotes an antibody, and to substitute for it the noncommittal 
expression "streptolysin S inhibitor." The latter term will be employed in the present paper. Further studies concerning the nature of the serum inhibitor of streptolysin $\mathrm{S}$ are presented in a subsequent report (9).

Recently Bernheimer (12) and Bernheimer and Rodbart (13), demonstrated that by incubating washed, resting streptococci with ribonucleic acid, or a polynucleotide derived therefrom, under specified conditions, a toxin of very high hemolytic potency is produced by the organisms and that it is identical with streptolysin S. The highly potent and purified streptolysin $S$ used in the present study was produced in this way.

\section{MATERIALS AND METHODS}

Clinical study. The following groups of patients were studied: (1) normal controls, (2) acute streptococcal pharyngitis, (3) acute rheumatic fever, (4) convalescent or quiescent rheumatic fever, and (5) a variety of miscellaneous diseases. Most patients in groups (2) and (3) were studied at the Streptococcal Disease Laboratory, Fort Francis E. Warren Air Base, Wyoming. The remaining sera were obtained from patients on the medical and pediatric services of the New York UniversityBellevue Medical Center and the Medical and Pediatric Services of the Mount Sinai Hospital in New York City.

Thirty-three cases of untreated, acute streptococcal pharyngitis were selected on the basis of the following criteria : Clinical evidence of acute pharyngitis characterized by sore throat with tonsillar exudate, high fever, and usually leucocytosis, the isolation of Group A streptococci from throat cultures, and the absence of specific chemotherapy (with the exception of one patient who received penicillin). Sera were obtained within a few days of the onset of the disease and again about three to four weeks later. Measurements of antistreptolysin $\mathrm{O}$ as well as streptolysin $S$ inhibitor were performed on all sera. Eleven of the strains of streptococci isolated were tested for production of streptolysin $S$ in vitro by the method of Bernheimer and Rodbart (13). All strains of streptococci isolated were classified by the method of Maxted (14) and Swift, Wilson and Lancefield (15).

Seventy-five cases of rheumatic fever were selected by the clinical criteria of history, fever, polyarthritis and carditis, supported by laboratory evidence of rapid erythrocyte sedimentation rate, leucocytosis, electrocardiographic changes and elevation of antistreptolysin $\mathrm{O}$ titer. Both salicylate treated and untreated cases are included. In 40 patients it was possible to follow the entire course of the disease and to obtain samples of serum at intervals of ten days throughout the illness. From three to eight serum samples were studied in each case and some patients were followed under hospital observation for eight months. A total of 61 patients was followed during the acute stage of the disease and the remaining 14 were seen only during convalescence from an attack of acute rheumatic fever.

Twelve of the strains of beta hemolytic streptococci isolated from these patients were tested for production of streptolysin $\mathrm{S}$ in vitro. Titers of antistreptolysin $\mathrm{O}$ and streptolysin $\mathrm{S}$ inhibitor were measured on all sera.

Titration of streptolysin $S$ serum inhibitor. Sera were stored at $4^{\circ} \mathrm{C}$. in instances where the tests were carried out within a few days after blood had been drawn. Storage at $-20^{\circ} \mathrm{C}$. was used for sera that were kept for longer periods. Under these conditions it has been found that there is no significant variation in titer (9). The details for the production of streptolysin $\mathrm{S}$ employed in this study have been described elsewhere (12). The toxin was stored in the lyophilized state and diluted just before use. The lot employed in this study had a potency of 20,000 hemolytic units per mgm. dry weight. A hemolytic unit of streptolysin $S$ has been defined as that amount of toxin in $1 \mathrm{ml}$. of saline-phosphate buffer which produces 50 per cent hemolysis of $1 \mathrm{ml}$. of a 0.7 per cent suspension of washed, human erythrocytes in 30 minutes

TABLE I

Titration of streptolysin $S$ inhibitor in serum

\begin{tabular}{l|l|l|l|l|l|l|l|l|l|l|l|l|l}
\hline \hline & \multicolumn{3}{|c|}{ Undiluted } & \multicolumn{1}{c}{ Diluted 1:10 } \\
\hline Serum (ml.) & 0.30 & 0.20 & 0.16 & 0.12 & 0.10 & 0.08 & 0.06 & 0.50 & 0.40 & 0.30 \\
\hline Saline-phosphate buffer (ml.) & 0.20 & 0.30 & 0.34 & 0.38 & 0.40 & 0.42 & 0.44 & 0.00 & 0.10 & 0.20 \\
\hline Streptolysin S, 4 hemolytic units (ml.) & 0.5 & 0.5 & 0.5 & 0.5 & 0.5 & 0.5 & 0.5 & 0.5 & 0.5 & 0.5 \\
\hline
\end{tabular}

Incubate for $10 \mathrm{~min}$. at $20^{\circ} \mathrm{C}$.

\begin{tabular}{l|l|l|l|l|l|l|l|l|l|l}
\hline Human RBC, 0.7 per cent (ml.) & 1.0 & 1.0 & 1.0 & 1.0 & 1.0 & 1.0 & 1.0 & 1.0 & 1.0 & 1.0 \\
\hline
\end{tabular}

Incubate for $30 \mathrm{~min}$. at $37^{\circ} \mathrm{C}$. and centrifuge

\begin{tabular}{|c|c|c|c|c|c|c|c|c|c|c|}
\hline $\begin{array}{l}\text { Units of streptolysin S inhibitor per ml. of serum } \\
\text { if hemolysis is completely inhibited }\end{array}$ & 3.3 & 5.0 & 6.3 & 8.0 & 10 & 12.5 & 16.7 & 20.0 & 25.0 & 33.0 \\
\hline
\end{tabular}


TABLE II

Percentage distribution of streptolysin $S$ inhibitor titers in the serum of normal humans and patients with various diseases

\begin{tabular}{|c|c|c|c|c|c|c|c|c|c|c|}
\hline \multirow{2}{*}{ Subjects } & \multirow{2}{*}{$\begin{array}{l}\text { No. of } \\
\text { Sera }\end{array}$} & \multicolumn{9}{|c|}{ Streptolysin $\mathrm{S}$ inhibitor units per $\mathrm{ml}$. } \\
\hline & & 4 & 5 & 6.3 & 8 & 10 & 12.5 & 16.7 & 20 & 25 \\
\hline $\begin{array}{l}\text { Normal } \\
\text { Streptococcal pharyngitis, acute } \\
\text { Streptococcal pharyngitis, }\end{array}$ & $\begin{array}{l}40 \\
30 \\
32\end{array}$ & $\begin{array}{l}\mathbf{0} \\
\mathbf{0} \\
\mathbf{0}\end{array}$ & $\begin{array}{l}\mathbf{0} \\
\mathbf{0} \\
\mathbf{0}\end{array}$ & $\begin{array}{l}2.5 \\
0 \\
0\end{array}$ & $\begin{array}{l}\mathbf{0} \\
\mathbf{0} \\
\mathbf{0}\end{array}$ & $\begin{array}{r}7.5 \\
10.0 \\
15.6\end{array}$ & $\begin{array}{l}40.0 \\
43.3 \\
40.6\end{array}$ & $\begin{array}{l}47.5 \\
36.6 \\
34.4\end{array}$ & $\begin{array}{l}2.5 \\
6.6 \\
3.1\end{array}$ & $\begin{array}{l}0 \\
3.3 \\
6.2\end{array}$ \\
\hline $\begin{array}{l}\text { Rheumatic fever, active } \\
\text { Rheumatic fever, convalescent }\end{array}$ & $\begin{array}{r}159 \\
89\end{array}$ & $\begin{array}{l}1.3 \\
0\end{array}$ & $\begin{array}{l}4.4 \\
0\end{array}$ & $\begin{array}{r}22 \\
0\end{array}$ & $\begin{array}{l}12 \\
1.1\end{array}$ & $\begin{array}{l}17.6 \\
19.1\end{array}$ & $\begin{array}{l}31.4 \\
55.1\end{array}$ & $\begin{array}{r}8.8 \\
15.7\end{array}$ & $\begin{array}{l}2.5 \\
7.9\end{array}$ & $\begin{array}{l}0 \\
1.1\end{array}$ \\
\hline
\end{tabular}

when incubated at $37^{\circ} \mathrm{C}$. Dilutions of serum and toxin were made in saline-phosphate buffer at $\mathrm{pH} 7.0(\mathrm{M} / 15$ phosphate and $\mathrm{M} / 12.9$ sodium chloride).

After heating for 30 minutes at $56^{\circ} \mathrm{C}$., the serum to be tested was diluted in saline-phosphate buffer through a range of $1: 3$ to $1: 33$. Because of the relatively narrow range of variation in the titer of streptolysin $S$ serum inhibitor, an increment between tubes of approximately 0.1 in the logarithm of the dilution factor was chosen. At this dilution increment, repeated tests with the same serum revealed a variation of no more than one tube in the endpoint. Streptolysin $\mathbf{S}$ was diluted in iced salinephosphate buffer so that $0.5 \mathrm{ml}$. of diluted toxin contained four hemolytic units. Five-tenths $\mathrm{ml}$. of diluted toxin was added promptly to each tube containing $0.5 \mathrm{ml}$. of serum dilution and the mixture incubated ten minutes at $20^{\circ} \mathrm{C}$. These conditions were chosen because of the heat lability of streptolysin S, particularly at high dilutions. One $\mathrm{ml}$. of a 0.7 per cent suspension of washed human erythrocytes was added to each tube and the tubes were incubated 30 minutes at $37^{\circ} \mathrm{C}$. The hemolytic action of the toxin was arrested by centrifugation of the tubes at room temperature for five minutes at a speed of about 1,500 r.p.m. in a No. 2 International centrifuge. The degree of hemolysis in the supernate was then noted. The 30-minute incubation period was measured from the time the erythrocytes were added to the time centrifugation was started. The endpoint chosen was the highest dilution of serum causing complete inhibition of hemolysis.

With each group of unknown sera, one or two standard sera were run as controls. Where variation of more than one dilution increment was encountered in the standard serum titration, the procedure was repeated. Where variation of one dilution increment occurred in the reading of the standard sera, the titers of the unknown sera were corrected by the appropriate factor. The number of units of streptolysin $\mathrm{S}$ inhibitor per $\mathrm{ml}$. of a given serum was expressed as the reciprocal of the quantity of serum producing complete inhibition of hemolysis under the conditions described above. Sera from slightly hemolyzed blood could be tested if a control series of dilutions of the same serum were run concomitantly, substituting buffer for toxin. Sera from intensely hemolyzed blood could not be used. Table I shows a protocol of a titration.

Antistreptolysin $O$ titration. The method used was essentially that described by Todd (16) with minor modifications.

Antistreptokinase titration. A small number of sera were tested by the method of Christensen (17) for comparison with antistreptolysin $O$ and streptolysin $S$ inhibitor titers determined on the same sera.

\section{RESULTS}

Normal human sera. The distribution of streptolysin $S$ inhibitor titers in the sera of 40 normal subjects, ranging in age from eight months to 60 years, is tabulated in Table II. The arithmetic mean of the titers of normal sera is 14.5 units. The values range from 10 to 20 units with the exception of a 10 month old child who had a titer of 6.3 units. Three other infants of the same age, however, had titers within the usual range found for normal adults. The lower limit of normal has been considered to be 10 units per $\mathrm{ml}$. of serum. No difference in titer was encountered between fasting and post-prandial, lipemic sera.

Acute streptococcal pharyngitis. A comparison of the streptolysin $\mathrm{S}$ inhibitor titers in the serum, obtained during the acute phase and in convalescence, of 33 patients with acute pharyngitis caused by Group A streptococci, is presented in Tables II and III. The arithmetic mean of the acute-phase sera is 14.5 units and that of the sera obtained during convalescence 14.4 units. It is evident that there is no increase in streptolysin $S$ inhibitor titer during convalescence and that the titers during the acute phase as well as in convalescence fall within the range encountered in normals. No serum in either group contained less than 10 units per $\mathrm{ml}$. and the highest titer encountered was 25 units per $\mathrm{ml}$. The corresponding antistreptolysin $\mathrm{O}$ titers show a two-fold or greater rise in 70 per cent of these patients. 
TABLE III

Comparative streptolysin $S$ inhibitor and antistreptolysin $O$ titers in the same serum samples of patients with streptococcal pharyngitis in the acute and convalescent stage

\begin{tabular}{|c|c|c|c|c|}
\hline \multirow{2}{*}{ Patient No. } & \multicolumn{2}{|c|}{$\underset{\text { (units per ml.) }}{\text { Streptolygin S. inhibitor }}$} & \multicolumn{2}{|c|}{$\begin{array}{l}\text { Antistreptolysin } 0 \\
\text { (units per ml.) }\end{array}$} \\
\hline & Acute & $\begin{array}{c}\text { Convales- } \\
\text { cent }\end{array}$ & Acute & $\begin{array}{c}\text { Convales- } \\
\text { cent }\end{array}$ \\
\hline $\begin{array}{l}\text { P-1730 } \\
\text { P-1875 } \\
\text { P-1699 } \\
\text { P-1815 } \\
\text { H-296 } \\
\text { P-1816 } \\
\text { P-1710 } \\
\text { P-1679 } \\
\text { P-1690 } \\
\text { P-1813 } \\
\text { P-1812 } \\
\text { P-1745 } \\
\text { P-1743 } \\
\text { P-1788 } \\
\text { P-1818 } \\
\text { P-1575 } \\
\text { P-1857 } \\
\text { P-1796 } \\
\text { P-1878 } \\
\text { P-1810 } \\
\text { P-1827 } \\
\text { P-42 } \\
\text { P-180 } \\
\text { P-155 } \\
\text { P-183 } \\
\text { P-97 } \\
\text { P-149 } \\
\text { P-2601 } \\
\text { P-161 } \\
\text { P-39 } \\
601 \\
602 \\
603\end{array}$ & $\begin{array}{l}12.5 \\
12.5 \\
10.6 \\
16.0 \\
12.5 \\
12.5 \\
12.5 \\
10.0 \\
16.7 \\
20.0 \\
20.0 \\
10.6 \\
16.0 \\
16.7 \\
16.7 \\
12.5 \\
12.5 \\
12.5 \\
12.5 \\
16.7 \\
16.7 \\
15.0 \\
12.0 \\
12.0 \\
15.0 \\
12.0 \\
16.7 \\
16.7 \\
12.5 \\
25.0 \\
- \\
- \\
-\end{array}$ & $\begin{array}{l}10.0 \\
12.5 \\
16.0 \\
16.0 \\
12.5 \\
12.5 \\
12.5 \\
10.0 \\
12.5 \\
20.0 \\
16.0 \\
10.6 \\
16.0 \\
16.7 \\
16.7 \\
12.5 \\
16.7 \\
12.5 \\
12.5 \\
16.7 \\
15.0 \\
12.0 \\
12.0 \\
12.0 \\
16.7 \\
16.7 \\
25.0 \\
12.5 \\
25.0 \\
10.0 \\
12.5 \\
10.0\end{array}$ & $\begin{array}{c}62.5 \\
159 \\
200 \\
125 \\
159 \\
159 \\
100 \\
50 \\
62.5 \\
125 \\
62.5 \\
62.5 \\
-62.5 \\
159 \\
200 \\
159 \\
100 \\
125 \\
125 \\
100 \\
317 \\
83.3 \\
62.5 \\
100 \\
83.3 \\
125 \\
83.3 \\
62.5 \\
- \\
- \\
-\end{array}$ & $\begin{array}{r}83.3 \\
500 \\
500 \\
125 \\
500 \\
400 \\
125 \\
400 \\
100 \\
250 \\
250 \\
125 \\
125 \\
400 \\
317 \\
500 \\
200 \\
100 \\
- \\
125 \\
317 \\
625 \\
159 \\
625 \\
159 \\
317 \\
200 \\
1000 \\
- \\
- \\
-\end{array}$ \\
\hline $\begin{array}{l}\text { Mean } \\
\text { (arithmetic) }\end{array}$ & 14.5 & 14.4 & 120 & 316 \\
\hline
\end{tabular}

The above observations on the behavior of streptolysin $\mathrm{S}$ inhibitor in the sera of patients with streptococcal pharyngitis are not in agreement with the results of Todd, Coburn and Hill who found that the mean titer of the sera of children with throat infections due to hemolytic streptococci was nearly twice as high as that of normal sera (1). To determine the normal level of streptolysin $\mathrm{S}$ inhibitor titer, these authors made use of specimens of serum which had been taken from adults for the Wassermann reaction, since normal figures for children were not available to them. Their study therefore differs from the present one in which the streptolysin S inhibitor titer of serum taken during the acute phase of illness is compared with that taken from the same patient during convalescence.

Streptolysin $S$ inhibitor titers in rheumatic fever. The distribution of streptolysin $S$ inhibitor titers in patients having acute rheumatic fever, as well as in patients convalescent therefrom, is presented in Table II. Table IV shows, in addition, the percentage of patients and of the total number of sera in each group that had a streptolysin S inhibitor titer of less than 10 units per $\mathrm{ml}$. It is apparent from these figures that the fall in streptolysin $\mathrm{S}$ serum inhibitor is a common phenomenon in acute rheumatic fever. Forty-nine of 61 cases ( 80 per cent) showed a titer of less than 10 units, and in almost every instance these low titers could be correlated with the period of severest rheumatic activity. Moreover, of the 49 patients showing this fall in titer during the acute phase, 42 had normal values during convalescence, one died with low values and the remaining six could not be followed through to convalescence.

The fall in streptolysin $\mathrm{S}$ inhibitor titer did not always occur promptly with the onset of rheumatic fever. In 15 of the 49 cases exhibiting this phenomenon, the serum drawn during the first few days of illness was normal and the fall in titer occurred only after the patient had been

TABLE IV

Percentage of patients and of serum specimens showing a streptolysin $S$ inhibitor titer of less than 10 units per ml.

\begin{tabular}{l|c|c|c|c|c}
\hline \multicolumn{1}{c|}{ Subjects } & No. of patients & $\begin{array}{c}\text { Mean streptolysin } \\
\text { S inhibitor }\end{array}$ & $\begin{array}{c}\text { Per cent of patients } \\
\text { <10 units per ml.* }\end{array}$ & $\begin{array}{c}\text { No. of serum } \\
\text { specimens tested }\end{array}$ & $\begin{array}{c}\text { Per cent of Sera } \\
<10 \text { units per ml. }\end{array}$ \\
\hline Normal & 40 & 14.5 & 2.5 & 40 & 2.5 \\
Rheumatic fever, acute & 61. & 10.3 & 80 & 159 & 41.7 \\
Rheumatic fever, convalescent & 69 & 13.4 & 1.4 & 0 & 1.1 \\
Streptococcal pharyngitis, acute & 30 & 14.5 & 0 & 30 & 0 \\
Streptococcal pharyngitis, convalescent & 32 & 14.4 & 0 & 32 & 0 \\
Miscellaneous diseases & 38 & 11.6 & 23.7 & 44 & 27.3 \\
\hline
\end{tabular}

* Patients showing a streptolysin $\mathrm{S}$ inhibitor titer of less than 10 units per ml. in one or more serum specimens are included in this group. 


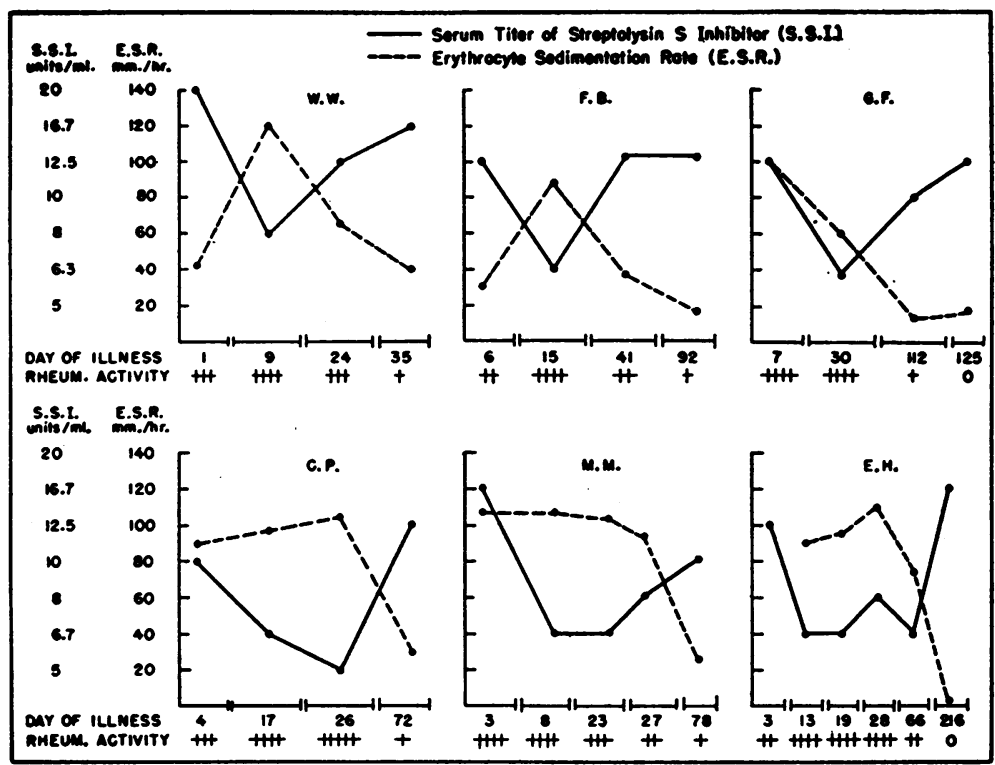

Frg. 1. Serum Titers of Streptolysin S In hibitor in Relation to Rheumatic Activity in Six Representative Cases of Acute RheuMATIC FEVER

severely ill for some time. Conversely, values usually returned to normal before rheumatic activity had completely subsided. Figure 1 shows the titers of six typical cases in relation to rheumatic activity, days of illness and erythrocyte sedimentation rate.

There was no clear-cut correlation of the fall in streptolysin $\mathrm{S}$ serum inhibitor with any particular clinical finding. In general, the lowest titers appeared in the sera of those cases showing the greatest debilitation and weight loss, although there were some exceptions to this observation. Moreover, the streptolysin $\mathrm{S}$ inhibitor titer does not appear to be influenced by salicylates since the titers were observed to vary independently of the administration of this drug. Salicylates were found neither to inhibit in vitro the activity of streptolysin $\mathrm{S}$ nor to affect the combination of the toxin with its serum inhibitor.

Similarly, the administration of adrenocorticotrophic hormone and cortisone, in two cases of rheumatic fever, did not appear to affect the streptolysin S serum inhibitor directly. One patient showed a persistently low titer (6.3 units) during treatment, and this corresponded with her failure to improve. The other patient had a rise in titer from a pre-treatment level of 6.3 units to 10 units after showing clinical improvement dur- ing treatment with ACTH. Three rheumatoid arthritis patients, two of whom were treated with ACTH and one with cortisone, showed, both before and after therapy, no variation from normal titer.

Relation of streptolysin $S$ inhibitor to antistreptolysin $O$ and antistreptokinase. Although none of the sera obtained from acute rheumatic fever patients, or from convalescents, had a streptolysin $\mathrm{S}$ serum inhibitor titer above 20 units (the normal upper limit), the antistreptolysin $\mathrm{O}$ and antistreptokinase titers of the same sera showed a marked elevation consistent with the patterns usually reported for these two antibodies in this disease (3). Eighty per cent of the patients with acute rheumatic fever showed a rise in antistreptolysin $\mathrm{O}$ titer to 400 units per ml. or higher, and 71 per cent of this same group showed a rise in antistreptokinase titer to 320 units or higher. The mean maximum titer of antistreptolysin $\mathrm{O}$ was 732 units and of antistreptokinase 887 units per $\mathrm{ml}$. Table $\mathrm{V}$ shows the comparative titers of the same serum sample in 34 cases of acute rheumatic fever at various stages of the disease. It is apparent that even in those sera showing striking elevation of both antistreptokinase and antistreptolysin $O$ titers, there is never a rise in streptolysin $S$ inhibitor above the normal range. 
TABLE V

Antistreptolysin $O$, antistreptokinase and streptolysin $S$ inhibitor titers of the same serum sample of rheumatic patients

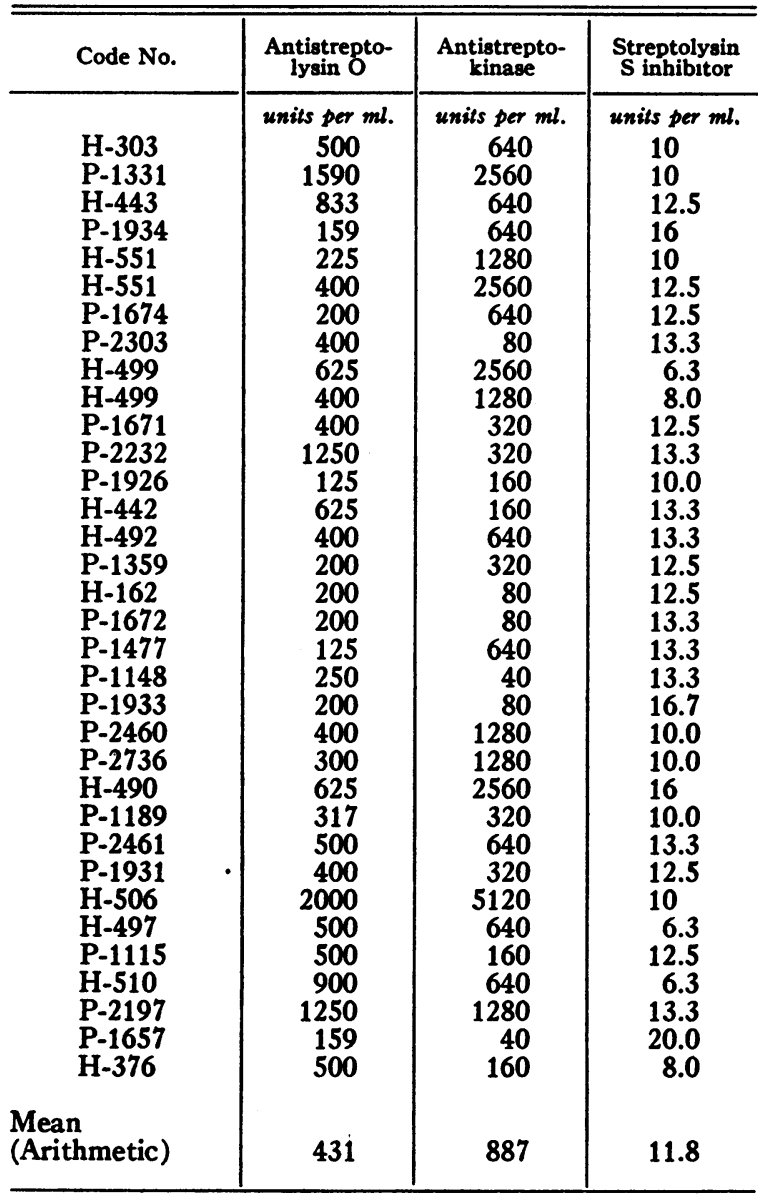

Production of streptolysin S by strains of Group $A$ streptococci. Eleven strains of Group A streptococci were isolated from the throats of $11 \mathrm{pa}$ tients with acute pharyngitis and 12 strains were isolated from the throats of patients with acute rheumatic fever. The types most commonly encountered were 5, 14, and 24. All 23 strains were shown to be capable of producing streptolysin $\mathrm{S}$ in vitro when incubated in broth to which a fraction of yeast nucleic acid had been added ("active fraction" of Bernheimer and Rodbart [13]). This is shown in Table VI.

Miscellaneous diseases. It was considered of importance to determine whether the tendency to low streptolysin S serum inhibitor titers during severe rheumatic activity is a specific phenomenon for this disease or whether a variety of other dis- ease states produce a similar effect. The streptolysin $S$ inhibitor titers in the sera of a group of 14 patients with severe rheumatoid arthritis were studied. Only one patient showed a titer below 10 units. This patient was a 55 year old man, with severe rheumatoid arthritis of three years' duration, whose streptolysin $\mathrm{S}$ inhibitor titer was 7 units per $\mathrm{ml}$. in each of two samples of serum drawn four weeks apart. The remaining patients, including a very severe case of Still's disease in a nine year old girl, had titers ranging from 10 to 20 units per $\mathrm{ml}$.

Several instances of low titers were encountered in a wide variety of diseases including disseminated lupus erythematosus, metastatic carcinomatosis, regional ileitis, tuberculous pleurisy and atypical pneumonia in a patient with inactive rheumatic fever. Table VII is a compilation of the titers in this miscellaneous group. It was not possible to correlate the low titers with any particular clinical finding such as fever or nutritional

TABLE VI

Production in vitro of streptolysin $S$ by strains of group $A$ streptococci isolated from patients with acute streptococcal pharyngitis and acute rheumatic fever

\begin{tabular}{|c|c|c|}
\hline Strains of group A streptococci & $\begin{array}{l}\text { Hemolytic titer } \\
\text { of plain broth } \\
\text { culture } \\
\text { (units per ml.) }\end{array}$ & $\begin{array}{c}\text { Hemolytic titer } \\
\text { of broth plus } \\
\text { ribonuclease- } \\
\text { resistant } \\
\text { fraction of } \\
\text { yeast nucleic } \\
\text { acid, } \\
0.2 \mathrm{mgm} \text {. per } \mathrm{ml} .\end{array}$ \\
\hline $\begin{array}{l}\text { Acute pharyngitis } \mathrm{P}-1679 \\
\text { P-155 } \\
\text { H-296 } \\
\text { P-183 } \\
\text { P-161 } \\
\text { P-97 } \\
\text { P-149 } \\
\text { P-42 } \\
\\
\text { P-180 } \\
\\
\text { P-39 } \\
\\
\text { Control }\end{array}$ & $\begin{array}{c}20 \text { hrs. at } 37^{\circ} \mathrm{C} . \\
<100 \\
<100 \\
<100 \\
<100 \\
<100 \\
<100 \\
<100 \\
<100 \\
<100 \\
<100 \\
<100 \\
150\end{array}$ & $\begin{array}{c}20 \text { hrs. at } 37^{\circ} \mathrm{C} \\
500 \\
1500 \\
350 \\
1125 \\
1250 \\
800 \\
1250 \\
125 \\
150 \\
500 \\
500 \\
1500\end{array}$ \\
\hline $\begin{array}{cl}\text { Rheumatic fever } & \text { P-2524* } \\
& \text { H-251* } \\
& \text { P-1477 } \\
& \text { P-1529* } \\
& \text { P-1926 } \\
& \text { P-2043* } \\
& \text { P-1933 } \\
& \text { P-1672 } \\
& \text { P-1657 } \\
& \text { P-1674 } \\
& \text { P-1931* } \\
\text { H-497 }\end{array}$ & $\begin{array}{l}<100 \\
<100 \\
<100 \\
<100 \\
<100 \\
<100 \\
<100 \\
<100 \\
<100 \\
<100 \\
<100 \\
<100\end{array}$ & $\begin{array}{r}200 \\
750 \\
1000 \\
1100 \\
850 \\
850 \\
400 \\
1250 \\
1250 \\
1250 \\
600 \\
1000\end{array}$ \\
\hline
\end{tabular}

* Isolated during the preceding streptococcal infection. 
TABLE VII

Streptolysin $S$ inhibitor titers in a group of miscellaneous diseases

\begin{tabular}{|c|c|c|}
\hline Disease & $\begin{array}{c}\text { No. } \\
\text { of } \\
\text { cases }\end{array}$ & $\begin{array}{l}\text { Streptolysin S } \\
\text { inhibitor titer } \\
\text { (units per mb.) }\end{array}$ \\
\hline Acute glomerulonephritis & 2 & $\begin{array}{l}12.5 \\
12.5\end{array}$ \\
\hline $\begin{array}{l}\text { Subacute glomerulonephritis } \\
\text { Chronic glomerulonephritis }\end{array}$ & $\begin{array}{l}1 \\
4\end{array}$ & $\begin{array}{c}12.5 \\
8^{*} \\
12.5 \\
16.7 \\
16.7\end{array}$ \\
\hline $\begin{array}{l}\text { Lipoid nephrosis } \\
\text { Erythema nodosum (streptococcal) } \\
\text { Subacute bacterial endocarditis }\end{array}$ & $\begin{array}{l}1 \\
1 \\
3\end{array}$ & $\begin{array}{l}20.0 \\
12.5 \\
10.0 \\
12.5 \\
5.0 ; 7.0^{*}+\end{array}$ \\
\hline $\begin{array}{l}\text { Scleroderma (terminal) } \\
\text { Disseminated lupus erythematosis } \\
\text { Primary atypical pneumonia } \\
\text { Atypical pneumonia, quiescent } \\
\text { rhuematic fever }\end{array}$ & $\begin{array}{l}1 \\
1 \\
1 \\
1\end{array}$ & $\begin{array}{l}13.0 \\
6.7^{*} \\
15 \\
4 ; 7.0^{*}\end{array}$ \\
\hline $\begin{array}{l}\text { Upper respiratory infection } \\
\text { Pericarditis, undetermined etiology } \\
\text { Tuberculous pleurisy and } \\
\text { pneumonia; chronic alcoholism }\end{array}$ & $\begin{array}{l}1 \\
1 \\
1\end{array}$ & $\begin{array}{c}16.7 \\
12.5 \\
6.7 *\end{array}$ \\
\hline $\begin{array}{l}\text { Diabetes mellitus } \\
\text { Congestive heart failure } \\
\text { (arteriosclerotic) }\end{array}$ & $\begin{array}{l}1 \\
1\end{array}$ & $\begin{array}{l}10.0 \\
12.5\end{array}$ \\
\hline $\begin{array}{l}\text { Congenital heart disease } \\
\text { (cyanotic type) }\end{array}$ & 1 & 12.5 \\
\hline $\begin{array}{l}\text { Metastatic carcinoma (terminal) } \\
\text { Regional ileitis } \\
\text { Rheumatoid arthritis }\end{array}$ & $\begin{array}{r}1 \\
1 \\
14\end{array}$ & $\begin{array}{l}8^{*} \\
8^{*} \\
12.5 \\
10.0 \\
12.5 \\
12.5 \\
10.0 \\
13 \\
7.0 ; 7.0^{*} \\
12.5 ; 12.5 ; 16.7 \\
16.7 ; 12.5 \\
14 \\
9 * \\
13 \\
16.7 \ddagger\end{array}$ \\
\hline
\end{tabular}

* Titer of less than 10 units per $\mathrm{ml}$.

+ Coexistent rheumatic activity could not be excluded.

$\$ 9$ year old girl with severe Still's disease.

deficiency. For example, the serum of a patient with severe scleroderma, obtained within an hour of death, still showed a normal titer of 13 units per $\mathrm{ml}$.

The percentage of patients and sera in this group having a titer of streptolysin $\mathrm{S}$ inhibitor below 10 units per $\mathrm{ml}$. is shown in Table IV. It is apparent that while 27.3 per cent of the sera of the miscellaneous group had titers less than 10 units compared with 41.7 per cent of the sera of patients with acute rheumatic fever, the former group is too heterogeneous to be strictly comparable with the latter. It is evident, however, that a low streptolysin $S$ inhibitor titer is not specific for rheumatic fever. Whether a low streptolysin $\mathrm{S}$ inhibitor titer occurs with greater regularity in rheumatic fever than in other diseases requires further investigation.

\section{DISCUSSION}

The tendency for the streptolysin S serum inhibitor to fall in patients with rheumatic fever, appears to be a frequent occurrence since it has been observed in 80 per cent of the rheumatic fever patients studied. It is possible that this figure might be even higher if sera were obtained more frequently during the peak of rheumatic activity. It is also apparent that the fall in titer is not a decrease in antibody, but more likely reflects a metabolic disturbance which results in a diminution of a normal component of serum. Studies concerned with the nature of the streptolysin $S$ inhibitor have shown it to be associated with phospholipid, probably bound in part to alpha and beta globulin fractions (9). Recent, independent observations of Humphrey $(10,11)$ also indicate that streptolysin $S$ inhibitor is not an antibody. This investigator has also given evidence for the lipid nature of the inhibitor and is of the opinion that it is probably bound in a protein complex to those alpha and beta globulin components of serum associated with lipids. It should be noted that neutral fat does not inhibit streptolysin S and that the titer of a post-prandial, lipemic serum does not differ from that of the fasting serum of the same individual. The nature of the disturbance in lipid metabolism influencing the serum level of streptolysin $S$ inhibitor is as yet unknown.

That the fall in streptolysin $\mathrm{S}$ inhibitor is not specific for rheumatic fever is demonstrated by the finding of low titers in some cases of diseases unrelated to streptococcal infection. The clinical factors that may be responsible for such low titers are not clear at present but they do not seem to be related to debilitating disease alone since some patients severely ill and in poor nutritional states have been found to have a normal level of streptolysin S serum inhibitor. It will require further and more detailed study of a larger and more diverse group of diseases to determine whether this phenomenon is more frequently encountered in rheumatic fever than in other patho- 
logical states, and whether it has any relationship to the pathogenesis of rheumatic fever.

There is general agreement that streptolysin $\mathrm{S}$, by itself, is not antigenic in animals $(7,9,10)$. Todd observed that a small proportion of rabbits develops a marked increase in serum inhibition of streptolysin $\mathrm{S}$ after intensive immunization of these animals with live cultures of beta hemolytic streptococci (7). In our hands (9), and in the the report of Humphrey (10), antibodies to streptolysin $\mathrm{S}$ were not produced under similar conditions. The reasons for this discrepancy in results are unknown. In addition, it should be noted that Humphrey has not been able to find evidence of antibody production against streptolysin $\mathrm{S}$ in a horse immunized with live cultures of the same organisms (10).

The failure of any patient, in the present study, to show an elevation of streptolysin $S$ inhibitor titer following proved streptococcal infection, or during the course of rheumatic fever when streptococcal antibodies have been demonstrated at very high levels, is evidence that streptolysin $S$ is not antigenic in man. The strains of streptococci isolated from this series of patients have all been shown capable of producing large amounts of this toxin in vitro in the presence of a ribonucleic acid fraction. The readiness with which this hemolysin is produced by streptococci in the presence of blood or serum also makes it appear probable that it is elaborated by these organisms in the tissues, and should therefore stimulate an antibody response if it were antigenic. The fact that it does not appear to do so is of some theoretical interest. Streptolysin S may be repeatedly liberated in the tissues of the host, as a result of recurrent streptococcal infections, without provoking an immune response against its possible noxious effects. What the pathological effects of this toxin are in man and what role streptolysin $\mathrm{S}$ inhibitor plays in natural resistance to streptococcal disease, remain to be.studied.

\section{SUMMARY}

1. Eighty per cent of patients with acute rheumatic fever showed a tendency for the serum level of streptolysin $\mathrm{S}$ inhibitor to fall below normal values during severe rheumatic activity and to return to normal levels during convalescence.
2. A low streptolysin $S$ inhibitor titer was also encountered in some cases of unrelated diseases and the fall, therefore, does not appear to be specific for rheumatic fever.

3. Thirty-three cases of acute pharyngitis due to Group A streptococci showed no significant change in streptolysin $\mathrm{S}$ inhibitor titer, and the values for sera drawn during the acute phase of the disease and during convalescence were within normal range.

4. In 75 cases of rheumatic fever there was no elevation of streptolysin $\mathrm{S}$ inhibitor titer beyond normal limits. In contrast, antistreptolysin $\mathrm{O}$ and antistreptokinase titers, measured on the same sera, rose to the high levels usually encountered in this disease.

5. Twenty-three strains of Group A streptococci isolated from the throats of patients with acute pharyngitis and from those with rheumatic fever were shown to be capable of producing streptolysin $\mathrm{S}$ in vitro.

6. These findings indicate that streptolysin $\mathrm{S}$ is not antigenic in man and that the capacity of serum to inhibit streptolysin $\mathrm{S}$ is due to a normal component of serum rather than to a specific antibody. The nature of the streptolysin $\mathrm{S}$ serum inhibitor and the significance of its decrease in rheumatic fever are discussed.

\section{ACKNOWLEDGMENTS}

The authors are grateful to Drs. Floyd W. Denny, Lewis W. Wannamaker, William R. Brink and Charles H. Rammelkamp for providing us with the clinical data and sera of the patients studied at the Streptococcal Disease Laboratory, Fort Francis E. Warren Air Base, Wyoming.

We are also indebted to Dr. Ann Kuttner and to the Study Group on Rheumatic Diseases of the New York University College of Medicine for their cooperation in obtaining many of the sera for this study.

\section{BIBLIOGRAPHY}

1. Todd, E. W., Coburn, A. F., and Hill, A. B., Antistreptolysin $S$ titres in rheumatic fever. Lancet, 1939, 2, 1213.

2. Mote, J. R., and Jones, T. D., Studies of hemolytic streptococcal antibodies in control groups, rheumatic fever, and rheumatoid arthritis. II. The frequency of antistreptolysin "O," antifibrinolysin and precipitating-antibody responses in scarlet fe- 
ver, hemolytic streptococcal infections, and rheumatic fever. J. Immunol., 1941, 41, 61.

3. Anderson, H. C., Kunkel, H. G., and McCarty, M., Quantitative antistreptokinase studies in patients infected with group A hemolytic streptococci: A comparison with serum antistreptolysin and gamma globulin levels with special reference to the occurrence of rheumatic fever. J. Clin. Invest., 1948, 27, 425.

4. Harris, T. N., and Harris, S., Turbidimetric measurement of streptococcal antihyaluronidase in the sera of patients with streptococcal infection and rheumatic fever. J. Immunol., 1949, 63, 249.

5. McCarty, M., The inhibition of streptococcal desoxyribonuclease by rabbit and human antisera. J. Exper. Med., 1949, 90, 543.

6. Herbert, D., and Todd, E. W., The oxygen-stable haemolysin of group A haemolytic streptococci (streptolysin S). Brit. J. Exper. Path., 1944, 25, 242.

7. Todd, E. W., The differentiation of two distinct serological varieties of streptolysin, streptolysin $\mathrm{O}$ and streptolysin S. J. Path. \& Bact., 1938, 47, 423.

8. Weld, J. T., The toxic properties of serum extracts of hemolytic streptococci. J. Exper. Med., 1934, $59,83$.

9. Stollerman, G. H., Bernheimer, A. W., and MacLeod, C. M., The association of lipoproteins with the in- hibition of streptolysin $\mathbf{S}$ by serum. To be published.

10. Humphrey, J. H., The nature of antistreptolysin "S" in the sera of man and other species: antistreptolysin titres in normal and diseased states. Brit. J. Exper. Path., 1949, 30, 345.

11. Humphrey, J. H., The nature of antistreptolysin $S$ in the sera of man and of other species. The lipoprotein properties of antistreptolysin S. Brit. J. Exper. Path., 1949, 30, 365.

12. Bernheimer, A. W., Formation of a bacterial toxin (streptolysin S) by resting cells.' J. Exper. Med., 1949, 90, 373.

13. Bernheimer, A. W., and Rodbart, M., The effect of nucleic acids and of carbohydrates on the formation of streptolysin. J. Exper. Med., 1948, 88, 149.

14. Maxted, W. R., Preparation of streptococcal extracts for Lancefield grouping. Lancet, 1948, 2, 255.

15. Swift, H. F., Wilson, A. T., and Lancefield, R. C., Typing group A hemolytic streptococci by $\mathrm{M}$ precipitin reactions in capillary pipettes. J. Exper. Med., 1943, 78, 127.

16. Todd, E. W., Antigenic streptococcal hemolysin. J. Exper. Med., 1932, 55, 267.

17. Christensen, L. R., Methods for measuring the activity of components of the streptococcal fibrinolytic system and streptococcal desoxyribonuclease. J. Clin. Invest., 1949, 28, 163. 